\title{
Effective at the Margins: Outmigration and Economic Development in Rural North Carolina
}

\author{
Jason Jolley (Corresponding author) \\ Carolina Center for Competitive Economies, University of North Carolina at Chapel Hill \\ Campus Box 3440, Kenan Center, Chapel Hill, NC 25799, USA \\ Tel: 1-919-843-6287_E-mail: Jason_jolley@unc.edu@ncu.ca
}

Aaron Nousaine

Carolina Center for Competitive Economies, University of North Carolina at Chapel Hill

Campus Box 3440, Kenan Center, Chapel Hill, NC 25799, USA

Tel: 1-919-672-3332 E-mail: aaronnousaine@unc.edu

Carolyn Huang

Carolina Center for Competitive Economies, University of North Carolina at Chapel Hill

Campus Box 3440, Kenan Center, Chapel Hill, NC 25799, USA

Tel: 1-919-843-6287 E-mail: carhuang@email.unc.edu

\begin{abstract}
Received: November 15, $2011 \quad$ Accepted: December 21, $2011 \quad$ Published: February 1, 2012
doi:10.5539/sar.v1n1p2

URL: http://dx.doi.org/10.5539/sar.v1n1p2
\end{abstract}

The research is based on a project funded by the Golden LEAF Foundation.

\begin{abstract}
This paper describes the economic and social challenges faced by Enfield, a small town in rural northeastern North Carolina, and the efforts by the Center for Competitive Economies at the University of North Carolina at Chapel Hill to assist the community in a strategic economic development plan to address these challenges. In particular, the paper outlines the challenges and tensions between place-based versus people-based economic development approaches and how these tensions are generalizeable to other rural small towns. Lastly, the paper concludes that even the most effective economic development strategies may only impact the community marginally given the larger confluence of events in the broader region, such as general population loss due to outmigration, declining traditional industries, and stagnant regional economies.
\end{abstract}

Keywords: Rural development, North Carolina, Population loss

\section{Introduction}

This paper describes the economic and social challenges faced by Enfield, a small town in rural northeastern North Carolina, and the efforts by the Center for Competitive Economies at the University of North Carolina at Chapel Hill to assist the community in a strategic economic development plan to address these challenges. In particular, the paper outlines the challenges and tensions between place-based versus people-based economic development approaches and how these tensions are generalizeable to other rural small towns. Lastly, the paper concludes that even the most effective economic development strategies may only impact the community marginally given the larger confluence of events in the broader region, such as general population loss due to outmigration, declining traditional industries, and stagnant regional economies.

\subsection{Background}

The Golden LEAF Foundation (Golden LEAF) was established by the North Carolina General Assembly to provide economic assistance in tobacco-dependent regions of the state, in accordance with the consent decree 
signed by the State of North Carolina and cigarette manufacturers. North Carolina was one of 46 states to bring litigation against manufacturers of tobacco products. In accordance with this mission, Golden LEAF contracted with the Center for Competitive Economies (the Center) at the University of North Carolina at Chapel Hill to create an economic development strategic plan on behalf of the Enfield Partnership for Tomorrow (the Partnership). Based in the Town of Enfield in southern Halifax County, the goal of the Partnership was to encourage economic growth and development within the existing service area of the Halifax Electric Membership Corporation, a rural electric cooperative serving southern Halifax and Warren counties. To this end, the Partnership had brought together local business leaders and government officials to begin the process of identifying and prioritizing community goals. While the Partnership had reached out to the African-American community, the organization was largely ineffective in generating sustained, active participation from the minority community. The Town of Enfield's population is 75 percent African-American and representation from this community was critical to creating a sustainable plan.

\section{Research Techniques and Approach}

The research plan developed by the Center sought to combine a data-driven, objective assessment of feasible economic development opportunities identified by the Center with the desired economic development outcomes expressed by the broader community. Within this context, the Center designed a strategic planning process that centered on a comprehensive community engagement effort. The intent was to promote equitable representation of African American residents, community leaders, and elected officials in the identification and prioritization of community economic development objectives. This involvement occurred in the form of semi-structured interviews conducted with known community leaders and public meetings designed to inform residents and solicit input. Additional research tasks were introduced to collect relevant background statistics on regional socio-economic conditions. These included a review of contemporary demographic and economic trends, an assessment of potential retail market gaps, an inventory of workforce characteristics, and a review of the dominant regional industry clusters. Once these tasks were completed, the research results were compiled and ranked based on community input. This was then translated into a multi-phase implementation strategy designed to guide the development and monitoring of new programs.

Of the many demographic trends identified, residential outmigration was the most likely to have a significant long-term impact on the area's economic vibrancy. Anecdotally, this was readily apparent to many active in the community. Some of the most active participants were native residents that moved away and returned in their retiring years. However, their education and professional success had often occurred outside of the broader Enfield region. This challenge of rural depopulation and residential outmigration was also supported in the data analysis. Over the past decade, only seven counties in the State of North Carolina experienced negative population growth. Five of those counties were located in the northeastern region of the state, including Halifax. The Town of Enfield and other communities in the southern portion of Halifax County are at the forefront of the depopulation trend with rates of population loss that greatly exceed the regional average (U.S. Census Bureau, 2011). Population loss and outmigration can be particularly troublesome for rural communities, as these trends often result in an increased the local tax burden, contraction of the local labor force, and reductions in gross household consumption.

For the purpose of analyzing relevant demographic data, the research team used Geographic Information Systems (GIS) to define four study areas that highlight Enfield's unique location between two dominant urban centers. These study area geographies are depicted in Figure 1. A one-mile radius was chosen to capture demographic and consumer conditions within the Enfield community itself. Five- and ten-mile radii were selected to offer a perspective on the southern Halifax County community that takes into account the rural populations living in the area surrounding Enfield. These households could be considered part of the potential Enfield consumer and labor pools, and should thus be considered in the analysis. A twenty-mile radius was also chosen to provide a comparison to the other three study areas, since it includes the two dominant regional population and employment centers of Roanoke Rapids and Rocky Mount.

\section{Population Loss and the Enfield Community}

Population loss is a major issue facing rural communities throughout the United States. Of more than two thousand rural, nonmetropolitan counties nearly half lost population over the past two decades. In over seven hundred of those counties, the rate of population loss exceeded ten percent (McGranahan, Cromartie, \& Wojan, 2011). This decline occurred through two distinct processes: natural change and outmigration. Natural changes in population occur when the birth rate and death rate diverge. All other things being equal, if the birth rate exceeds the death rate, the population increases. If the death rate exceeds the rate at which children are being born, the 
population declines. Natural population change typically occurs quite slowly, perhaps with the exception of major conflict events and epidemic disease. Outmigration, by comparison, can occur quite rapidly as residents relocate to other areas seeking improved economic opportunity and a higher standard of living. Yet, the outmigration of individuals and households does not always result in a net loss of population. The outflow of residents must be large enough to offset the number of residents migrating into the area from outside, as well as any natural population growth that might occur. Much more volatile than natural population change, outmigration rates typically reflect the local conditions present in a community (McHugh \& Gober, 1992). In addition to economic considerations, residential relocation choices are highly influenced by various quality-of-life factors. These can include the individuals place in the life-cycle, the quality of the local schools, the affordability of area housing, and access to a diversity of retail shopping outlets. It is this volatility and interrelatedness with other community characteristics that makes outmigration the primary focus of academic research and policy analysis (McGranahan et al., 2011; Butmann, Deane, \& Peri, 2005; McHugh \& Gober, 1992).

\subsection{Outmigration and the Life-Cycle}

An individual's stage in the life cycle has a strong influence on their propensity toward outmigration (Plane \& Jurjevich, 2009; Cromartie \& Nelson, 2009). The highest rates of outmigration typically occur among young adults in their late teens and early twenties. These individuals, after graduation from high school, often migrate to major metropolitan cities to attend college, serve in the military, or pursue other career opportunities. As people age, the propensity for migration decreases and the geographic focus shifts from the urban core to the suburban fringe. By the time someone reaches their mid-forties, the likelihood of relocation has declined by around half. In addition to a reduced proclivity toward migration, older individuals and married couples with children have a greater preference for quality-of-life factors, like good quality schools, compared to their younger counter parts. This makes older households more likely to in-migrate to rural communities, often countering the outmigration of younger adults.

The challenge is that communities experiencing various types of economic and social distress are statistically more likely to lose young adults to outmigration faster than they can gain older adults and families through in-migration. McGranahan et al. (2011) reported that rural counties not experiencing any net population loss through outmigration, gained population at an average rate of one percent per year. While these counties still lost young adults, they experienced a net gain due to the in-migration of families and older individuals. Counties that experienced net outmigration, but that did not exhibit severe economic distress, also lost young adults, but at a much faster rate. These counties also failed to attract a sufficient cohort of young families and older adults. As these households are more sensitive to quality-of-life considerations, it can be inferred that low-poverty counties experiencing high net outmigration possess fewer desirable residential amenities. By comparison, rural counties that experienced severe economic distress and high net outmigration lost both young adults and young families, while also failing to attract older adults and retirees. What can be concluded from these findings is that the factors influencing relocation choices differ by age cohort and that adverse economic conditions can worsen trends of outmigration caused by a lack of desired amenities.

\subsubsection{Life-Cycle Dynamics in Enfield and Southern Halifax County}

Of the many demographic trends identified during the strategic planning process, residential outmigration was the most likely to impact the area's long-term economic vibrancy. Of the seven counties in North Carolina that lost population over the past decade, the Town of Enfield and other communities in the southern portion of Halifax County were at the forefront of the depopulation trend with rates of population loss that greatly exceed the regional average (U.S. Census Bureau, 2011). As previously shown in Table 1, the population of Enfield - as represented by the 1-mile radius - declined by ten percent between the year 2000 and 2010. Similar trends were evident in the 5- and 10- mile areas with a total decrease in population of 12 and 11 percent respectively. The 20-mile radius that included the cities of Roanoke Rapids and Rocky Mount showed a decline in population of only around one percent. This confirmed that while the county as a whole had lost population, urban areas were much less affected than rural ones.

Armed with this information, the research team investigated the distribution of population by age cohort. All four study areas showed similar proportional distributions. What was more telling was the rate at which the four study areas were gaining and losing population within each age group. Table 2 reports the absolute and annual average rate of change within each of the seven age groups. Within the 1-mile radius, there were significant losses in the under 18 and 35-44 age groups. These lost population at an average rate of 2.3 and 3.8 percent per year. Alternatively, there were two age groups that also exhibited modest gains. These included the 25-34 and 55-64 
age groups. The rates of population growth in these two groups, however, were only around 0.9 and 1.4 percent per year. As the rates of population growth in these two categories were substantially lower than the rates of population loss in the remaining age groups, the net outcome within the 1-mile radius was a decrease in population. The 5- and 10-mile radii showed similar population changes, with high rates of population loss in the under 18 and 35-44 age groups. However, within these areas, the net positive population growth seen in the 25-34 age category had reversed sign, showing a negative growth trend. Lastly, the 20-mile radius showed a 1.1 percent decline in the under 18 age group, as well as a 0.7 percent decline in the $25-34$ age group and a 2.4 percent decline in the 35-44 age group. The area showed modest gains in the 18-24 age range and substantial gains in the 45-54, 55-64, and 65 and over age groups.

What the age based population growth trends indicated was that Enfield and southern Halifax County were losing young adults, families, and older adults. Rapid declines in the number of residents in the under 18 and 18-24 age groups suggested that a large number of young adults were leaving the community. The fact that the proportional concentration of residents within the 18-24 age group did not change significantly suggested that the rate of population loss within the age group remained relatively stable over time. More concerning was the increasingly rapid loss of families, represented by the under 18 and 35-44 age groups. These households made up nearly 42 percent of the population in the year 2000. By 2010, this had decreased to 35 percent. Interviews carried out with residents located in and around the Town of Enfield confirmed that an under-performing and somewhat segregated school system, a lack of retail shopping outlets, and perceived problems of crime and juvenile delinquency were among the most important reasons why the area had failed to retain many of its families and older adults.

\subsubsection{Population Loss and Racial Composition}

One other important demographic shift related to population loss is the increasing prominence of the African-American population in southern Halifax County. As seen in Table 3, the racial and ethnic breakdown suggests a community that is primarily African American. The proportion of households in the 1-mile radius reporting as white decreased from around 28 percent in 2000 to 23 percent in 2010 . This corresponded to an increase in the proportion of Households reporting to be African American, from 70 percent in 2000 to 76 percent in 2010. Data for the 5- and 10-mile radii report similar trends. The 20-mile radius, however, shows a more even split between white and African American households. In the year 2000, around 49 percent of households reported to be African American, while 47 percent reported to be white. By 2010, the mix shifted slightly to include roughly 51 percent African American households and 44 percent white households. What these figures indicate is that the rate of population loss was much higher among white households, resulting in a community that is increasingly African-American.

\subsubsection{School Quality and Legacy of Segregation}

The community engagement effort undertaken by the Center revealed a deep seated discontent among area residents with the quality of the local school system and other social conditions in the greater Enfield area. While research was being conducted for this project, the UNC Center for Civil Rights released a report discussing the impacts of the persistent racial and socio-economic segregation of Halifax County students (Dorosin, Haddix, Jones \& Trice, 2011). The county is one of only a handful in the state with three separate school districts. The Roanoke Rapids Graded School District (RRGSD) and the Weldon City Schools (WCS) serve students in the urbanized areas of Roanoke Rapids and Weldon. The Halifax County Public Schools (HCPS) serve students in the unincorporated parts of Halifax County. The most striking difference between the three districts is that nearly 100 percent the students enrolled in the WCS and the HCPS in 2009 were African-American, while 70 percent of the students enrolled in the RRGSD were white. The WCS and the HCPS were also heavily low-income in 2009, with over 90 percent of students receiving Free and Reduced Lunch (FRL). In the RRGSD around 51 percent of students were enrolled in the program. While the percent of students enrolled in the FRL program in the RRGSD is still quite high, the percent enrollment in the WCS and HCPS is truly staggering.

This racial and economic segregation has had important impacts on educational outcomes in southern Halifax County. For example, the proportion of students in grades three through eight that scored at or above grade level on their End-of-Grade (EoG) reading exams during the 2009-2010 school year was only 37 percent in the HCPS and 47 percent in the WCS. This is compared to almost 68 percent in the RRGSD. While the percentage of students reading at grade level in all three districts is quite low, the magnitude of the difference between the RRGSD and the other two districts indicates a clear difference in school quality. The UNC study also measured three indicators of school quality, in addition to student performance. These were teacher turnover, teacher working conditions, and teacher quality. Table 4 reports teacher turnover rates for the three school districts. In 
almost every measure, the HCPS and WCS experienced significantly higher rates of teacher turnover. This can be partially explained by a greater feeling of frustration among teachers within the two minority-majority school districts. Teachers in these schools identified a sense of tension within the community, a lacking sense of trust and respect within the working environment, and a feeling that the school environments were not "conducive to learning" (Dorosin et al., 2011). Some of these feelings of unease, however, may be related to the relative inexperience of many of the teachers in the HCPS and WCS school districts. The report indicates that between 25 and 30 percent of the teaching staff in these districts have three years or less of teaching experience. This is compared to only six percent in the RRGSD.

This relative inexperience - as well as the other issues within the two minority school districts - is likely a symptom, of funding disparities between the three districts. The annual budgets of the WCS and RRGSD are augmented by revenues drawn from local property taxes. The WCS receives revenue at a rate of 17 cents per $\$ 100$ of value. The RRGSD, by comparison, receives 21 cents per $\$ 100$. Due to the higher tax rate, as well as the higher value of property located in the City of Roanoke Rapids, the RRGSD receives substantially more supplemental revenue than the Weldon district. The majority of the funds received are used to pay wage supplements to teachers as a recruitment and retention incentive. In the 2009-2010 academic year, the RRGSD paid an average of $\$ 1,795$ per teacher. The WCS paid only $\$ 373$, while the HCPS could not provide such wage supplements (Dorosin et al., 2011). Because of these disparities between the districts, the HCPS have found it difficult to recruit and retain high quality teachers.

With less experience, lower test scores, less operational revenue, and a primarily disadvantaged student body, the HCPS has become one of the lowest-performing districts in the state. As such, it is also a major deterrent to the in-migration of potential residents who value high quality education. For instance, the 1996 Rural Manufacturing Survey identified labor quality as a major issue for rural manufacturers and indicated poor school quality as a barrier to the recruitment of upper level management. In terms of labor quality, worker reliability and attitude were the most frequently cited problems for manufacturers (McGranahan, 1998). This concern was echoed by Enfield area residents who described the challenges faced by recent high school graduates when they tried to secure employment. Many, it was noted, lacked even the basic soft skills necessary to be successful in the labor market. These included the ability to arrive on-time, to follow directions, and to groom one's self in a manner befitting a work environment. Thus, the local area schools fail to provide even the basic level of education necessary to serve area residents. Lacking this essential service, it is no wonder that the county remains unable to attract families in sufficient numbers to offset the loss of young adults.

\subsubsection{Employment and Wages of Halifax County Workers}

While high net outmigration in nonmetropolitan communities is strongly influenced by non-economic quality-of-life factors, research indicates that high rates of poverty and economic distress can exacerbate trends of outmigration (McGranahan et al., 2011). Halifax County, at the time of this research, was already one of the most economically distressed communities in the state. Between 2000 and 2010, the county lost over 2,400 jobs. The majority of these losses occurred in the goods-producing industries of manufacturing, construction, and natural resource extraction, which lost jobs at a rate of roughly six percent per year over the decade. Manufacturing experienced the most substantial losses with over 1,740 layoffs. Significant losses also occurred in the service-providing industries of trade and transportation, information technology, business services, and public administration. The net effect of these jobs losses was an increase in the county-wide unemployment rate from only six percent in 2000 to over 13 percent in 2010. This is compared to only 10.6 for the state as a whole.

While the county and state both experienced increases in the unemployment rate over the past decade, both appear to have experienced a moderate degree of nominal wage growth. Data collected from the Quarterly Census of Employment and Wages (QCEW) indicated that without adjusting for inflation, workers in Halifax County experienced an average annual increase in pay of roughly 2.1 percent (U.S. Bureau of Labor Statistics, $2011 \mathrm{a})$. This raised the average annual wage from around $\$ 24,000$ to over $\$ 29,600$. At the industry level, the sectors that experienced the most rapid wage growth were mostly in the goods-producing sectors. In terms of high- and low-wage industry sectors, the goods-producing sectors also had the highest average wages at roughly $\$ 40,700$ per year compared to only $\$ 27,500$ per year on average in the service-providing sectors.

While positive nominal wage growth is an important indicator of labor market competitiveness, it is important to consider whether or not growth in local wages meets or exceeds the rate of inflation. In addition to nominal wage rates, the research team also calculated annual average wage figures that adjusted for inflation using the Bureau of Labor Statistics Consumer Price Index for the South Region (U.S. Bureau of Labor Statistics, 2011b). According to these figures, the average annual wage in Halifax County has actually declined in real terms by 
almost $\$ 160$. Goods-producing industries appear to have maintained positive wage growth equal to an increase in annual pay of nearly $\$ 4,400$. Service-providing industries, however, experienced a drop in annual wage of almost $\$ 100$ per year.

Together these trends in employment and wages suggest that Halifax County as a whole is under performing economically, compared to the state. It experienced employment losses in nearly all industry sectors over the last decade and only modest employment growth in the two industries that are not in decline. While employee wages have nominally increased over time, they have failed to keep up with inflation, leaving Halifax County at a competitive disadvantage compared to other parts of the state for worker recruitment and retention. The only industries that appeared to be wage competitive were the goods-producing sectors whose wages had remained at around 85 to 90 percent of the state average. Unfortunately, these are the same industries which were losing jobs at the highest rate.

\subsubsection{Poverty and Income Dynamics}

Symptomatic of prolonged unemployment, declining wages, and poor educational achievement, Enfield and southern Halifax County also experienced high rates of poverty and increasing income inequality between white and African-American residents. In Halifax County as a whole, roughly 24 percent of residents reported incomes at or below the federal poverty limit in both the 2000 Census and 2009 American Community Survey (ACS). Local level estimates for the Town of Enfield report a poverty rate of roughly 34 percent in both the Census and 2005-2009 ACS. This suggests that while poverty rates were high, they remained relatively stable over time, despite the recent recession.

In order to further illustrate the socio-economic disparities that exist between the African American and the white households, data were collected on median household income by race and ethnicity. Table 5 shows the inflation adjusted and non-inflation adjusted median household incomes for households by race of householder in 1999 and 2010. According to this data, the median African American household income in 1999 in the 1-mile radius was roughly 52 percent lower than that of white households. After adjusting to 2010 dollars, this was equal to a median white household income of over $\$ 48,000$ per year, compared to only $\$ 23,000$ per year for the median African American household. This disparity increased in 2010 where the median African American household income was roughly 54 percent less than the corresponding median white household income. The income disparity reported in the other three study areas for 1999 and 2010 was somewhat less than in the 1-mile area, but continued to reflect median African American household incomes that were between 42 and 48 percent lower than for their white counterparts.

To highlight another important characteristic of the Enfield community, Table 6 reports the number of households who received income from certain sources. What is important to recognize is that Enfield has a lower relative proportion of households drawing on traditional sources of income, such as wages/salary, self-employment, and interest, dividends, and rental income from real estate. Enfield also has a higher proportion of households that partake in various types of public assistance, like social security, public assistance, disability income, and unemployment income. The complicating factor was that the earnings source categories reported are not mutually exclusive. Households could feasibly be reported as drawing income or earnings from multiple sources.

\section{Place-Based Versus People-Based Economic Development}

The purpose of economic development has widely been accepted as raising standards of living for current residents, but economic developers have achieved little consensus on how these goals ought to be operationalized. In the 1960s, researchers and practitioners were divided over the best development methods to deal with spreading urban poverty and urban blight. The discussions raised questions about how economic development could best address poverty and whether the focus should be on people-based or place-based economic development strategies (Kain \& Persky, 1969). Decades of economic projects and research have not resolved these divisions (Kraybill \& Kilkenny, 2003).

\subsection{What is Place-Based Economic Development}

Place-based policies are distinctive from people-based development because the primary target is the locality, not just the individual residing there (Bolton, 1992). A development strategy that promotes the growth of the local economy also promotes its residents' living standards (Krayhill \& Kilkenny, 2003). Proponents of place-based strategies argue that meaningful economic development strategies cannot occur without considering the context with which people live (Butler, 1991; Johnson, 2007). Policies such that enhance comparative advantages and location "uniqueness" enable a place to compete openly in a market for new industries, businesses, or residents 
(Kraybill \& Kilkenny, 2003) and are therefore are much more contextualized to the intricacies of its locality (Blank, 2005; Olfert \& Partridge, 2010).

From this theoretical basis, place-based policies like industrial recruitment and industry cluster development have been attractive methods during the 1960s and 80s (Johnson, 2007) because they increase job growth rapidly in economically depressed areas, especially in areas where low-skill workforce and mobility are prevalent (Patridge \& Richman, 2006). However, these policies may be costly and low yield, achieving only limited gains through primarily low-wage jobs. Critics also cite that harm stems from this type of quick-paced development (Crowe, 2006). Additionally, industrial recruitment strategies may lead rural communities to engage in a race to the bottom competition against each other, by offering expensive economic incentive packages at cost to greater community development.

The pure place strategy adopts a similar approach except applied to a larger geographical area, focuses on "improving the economic well-being of people in a geographic area extending well beyond the boundaries of the targeted area rather than to help only the residents of the targeted area" Ladd (1994). The belief is that if one community is able to flourish, its development will produce positive externalities for poorer neighboring communities. However, as was observable through this study, disparity across communities encourages out-migration from job-barren, economically distressed communities into their wealthier counterparts and may create a cycle of systematic preference where regional officials continue to invest their development programs into higher-performing communities. Moreover, such strategies are less ideally suited for long-term sustainable development for rural communities (Flora et al., 1992).

Alternatively, the place-based approach called "self-development" or "endogenous growth" approaches emerged in contrast to external growth stimulation. Self-development encourages and supports business development from within the community, drawing from local resources (Flora et al. 1992; Crowe, 2006). Such strategies can produce limited yields for a rural community - smaller numbers of jobs - while requiring large capital costs and technical assistance, which rural communities may not necessarily have. Furthermore, rural communities which were successfully able to implement self-development strategies were associated to also be successful with industrial recruitment strategies (Flora et al. 1992).

\subsection{What is Place-Based Economic Development}

The earliest forms of support for the person-based approach came from the urban development literature, where it was presented as an alternative to directly address the spatial dimensions of poverty, specifically the ghetto. Kain \& Persky (1969) argued that place-based strategies overlooked the systematic factors which perpetuate poverty, such as disparate access to quality education, employment opportunities, and the psychological and social effects of living in low-income areas. People-based economic development focuses on developing human capital of poor, low-skilled individuals and increasing individual capability to compete in, and access formal labor markets. This may occur through education programs or skills training, transportation assistance to places of employment, or transfer payments and subsidies that enable them to leave their communities (Kain \& Persky, 1969), but the ultimate goals is to promote the individual's labor capability, irrespective of locality, usually in a "spatially neutral," way to promote equitable access to resources (Olfert \& Partridge, 2010).

Olfert \& Partridge (2010) note that there is a "somewhat artificial distinction" between the types of policies. That is, the two development agendas have overlapping objectives that prevent a single, neat categorization of either policy. However, the greater lesson should not be in drawing distinctions, but that the bottom line of economic development is to raise living standards for members of a community. One strategy should not preclude another - the community cannot successfully thrive without considering the least advantaged members of its community. Persistent poverty is not simply inequitable, but leads to social and economic problems for the community; communities cannot succeed without thriving businesses and a strong tax base. Sound economic development must assume a balance of both approaches.

Furthermore, what these debates miss, and what critics on either side have come to realize, is that Intangible social goods, such as an educated workforce, social capital, e.g., a sense of community (Bolton, 1992; Crowe, 2006), and motivation for change are drivers for entrepreneurship and innovation (Olfert \& Partridge, 2010; Faggian \& McCann, 2009). Such intangible benefits are described as "security of stable expectations, and security of being able to operate in a familiar environment and to trust other citizens" (Bolton, 1992).

\section{Conclusions and Recommendations}

The Center's strategic economic development recommendations focused on both people-based and place-based strategies. The plan recognized that even the most successful economic development efforts likely would have 
marginal effects on the broader Enfield community in the short term, but could set the stage for a better future for both the place and the people of the Enfield.

The Center first identified a set of industry clusters where the larger community had a potential competitive advantage. These focused heavily on the wood processing industries due to the abundance of timberland in the area and on small scale, value added food processing where the county has demonstrated recent and historical economic development success. It was suggested that Enfield not compete with the larger industrial sites in the region, but focus on niche, smaller scale businesses requiring less space.

Second, despite a relatively weak consumer market due to low incomes and a substantial population relying on government assistance programs, Enfield leaks much of its retail sales to the surrounding region. A list of retail development targets were identified for expansion into Enfield along with suggestions for how the local governments should provide assistance, concessions or incentives to promote retail location. These included financial assistance as retail sales or property tax breaks, concessionary financing (e.g. low-interest loans), and low-cost land, etc. The community may also offer non-financial forms of assistance, such as help creating a business plan or locating a store.

Third, the Center recommended that Enfield capitalize on its historic downtown commercial buildings historic residential structures. Several ongoing projects in the community included the renovation of a former historic home into a bed and breakfast and the restoration of a Masonic lodge into a theatre. It was recommended the Town pursue a formal historic district and identify historic properties to engage some pre-qualifying steps for current and future property owners to utilize federal and state historic rehabilitation tax credits to help finance their projects.

It was also recommended that the community leverage the inventory of existing historic homes for a "heritage housing" program to market these homes to potential newcomers, retirees, and others seeking relocation to North Carolina. This approach included using social networks and connections that already exist in the community, identify those individuals who have strong personal connections to the Enfield area, but who do not currently live here. In particular, efforts should focus on persons with the skills and assets that can provide important benefits to the community, such as entrepreneurs, educators, and professionals. Recruitment efforts should emphasize the availability of historic homes.

Several people-based strategies were also recommended to help the citizens of the Enfield area improve their lives and economic well-being. These included tackling the most prominent challenge of three school systems largely segregated on the basis of race and working to improve educational attainment in the community. Second, it was recommended that the community engage in recreational and vocation programs to engage youth, particularly in afterschool activities. Such programs will provide safe alternatives and address the youth delinquency and crime problems faced by the community. Third, it was recommended that the Partnership activity broaden participation and leadership opportunities for minority residents. This included reach out to local churches to encourage minority participation in the ongoing economic development planning and implementation efforts and inviting the mayor, town council members and town staff to participate in regular meetings and community events.

The challenged faced by Enfield are representative of the challenges faced by many post-agricultural and rural small town communities experiencing economic stagnation and depopulation. Communities facing these challenges are limited, especially in the short-term, in their options to address these challenges. Our findings suggest that communities should work to broaden public involvement to be inclusive and diverse in identifying community desires. Communities should also work to capitalize on their competitive advantages to retain and attract employment, even if these require pursuing nontraditional economic development approaches such as recruitment of retail stores or renovation of historic properties. Lastly, it is difficult for a small community facing broader trends of depopulation to buck the tide and continue to develop a strong place-based economic development strategy. Those communities should continue to work on people-based approaches to equip their citizens with the skills to allow them to out-migrate as needed to better employment options in other geographies.

\section{References}

Blank, R. (2005). Poverty, Policy, and Place: How Poverty and Policies to Alleviate Poverty are Shaped by Local Characteristics. International Regional Science Review, 28, 441-464. http://dx.doi.org/10.1177/0160017605278999

Bolton, R. (1992). 'Place Prosperity vs. People Prosperity' Revisited: An Old Issue With a New Angle. Urban 
Studies, 29(2), 185-203. http://dx.doi.org/10.1080/00420989220080261

Butler, S. (1981). Enterprise Zones: Greening the Inner Cities. New York, NY: Universe Books.

Butmann, M., Deane, G., \& Peri, A. (2005). Two Population-Environment Regimes in the Great Plains of the United States, 1930-1990. Population \& Environment, 27(2), 191-225. http://dx.doi.org/10.1007/s11111-006-0016-3

Cromartie, J., \& Nelson, P. (2009). Baby Boom Migration and Its Impact on Rural America (Economic Research Report No. 79). Washington, DC: U.S. Department of Agriculture. http://www.ers.usda.gov/publications/err79/

Crowe, J. (2006). Community Economic Development Strategies in Rural Washington: Toward a Synthesis of Natural and Social Capital. Rural Sociology, 71(4), 573-596. http://dx.doi.org/10.1526/003601106781262043

Dorosin, M., Haddix, E., Jones, B., \& Trice, C. (2011). The State of Education in Halifax County. Chapel Hill, NC: University of North Carolina, Center for Civil Rights. http://www.law.unc.edu/centers/civilrights/agenda/educational/halifaxstate.aspx

Faggin, A., \& McCann, P. (2009). Human Capital, Graduate Migration, and Innovation in British Regions. Cambridge Journal of Economics, 33, 317-333. http://dx.doi.org/10.1093/cje/ben042

Flora, J., Green, G., Gale, E., Schmidt, F., \& Flora, C. (1992). Self Development: A Viable Rural Development Option? Policy Studies Journal, 20, 276-288. http://dx.doi.org/10.1111/j.1541-0072.1992.tb00155.x

Johnson, T. (2007). Place-Based Economic Policy: Innovation or Fad? Agricultural and Resource Economics Review, 36(1), 1-8. http://purl.umn.edu/10160

Kain, J., \& Persky, J. (1969). Alternatives to the Gilded Ghetto. Public Interest, 14, 74-87. http://pao.chadwyck.com/PDF/1324492637699.pdf

Kraybill, D., \& Kilkenny, M. (2003). Economic Rationales For and Against Place-Based Policies [Staff General Research Paper No. 11730]. Ames, IA: Iowa State University, Department of Economics. http://reimer.concordia.ca/files/PlaceBased/PlaceBasedPolicyKraybill,Kilkenny.pdf

Ladd, H. (1994). Spatially Targeted Economic Development Strategies: Do They Work? Cityscape, 1(1), 193-218. http://www.huduser.org/periodicals/cityscpe/vollnum1/ch10.pdf

McGranahan, D., Cromartie, J., \& Wojan, T. (2011). Persistence nonmetropolitan outmigration counties: Some are poor, many are prosperous [Economic Research Report No. 107]. Washington, DC: U.S. Department of Agriculture. http://www.ers.usda.gov/Publications/ERR107/ERR107.pdf

McGranahan, D. (1998). Local Problems Facing Manufacturers: Results of the ERS Rural Manufacturing Survey [Agriculture Information Bulletin No. 736-03]. Washington, DC: U.S. Department of Agriculture. http://www.ers.usda.gov/publications/aib736/aib73603.PDF

McHugh, K., \& Gober, P. (1992). Short-Term Dynamics of the U.S. Interstate Migration System, 1980-1988. Growth \& Change, 23(4), 428. http://dx.doi.org/10.1111/j.1468-2257.1992.tb00943.x

Olfert, M., \& Partridge, M. (2010). Best Practices in Twenty-First-Century Rural Development and Policy. Growth and Change, 41(2), 147-164. http://dx.doi.org/10.1111/j.1468-2257.2010.00523.x

Partridge, M., \& Rickman, D. (2006). The Geography of American Poverty: Is there a Need for Place-Based Policies? Kalamazoo, MI: W.E. Upjohn Institute for Employment Research. http://www.upjohn.org/publications/titles/gap.html

Plane, D., \& Jurjevich, J. (2009). Ties That No Longer Bind? The Patterns and Repercussions of Age-Articulated Migration. Professional Geographer, 61(1), 4-20. http://dx.doi.org/10.1080/00330120802577558

U.S. Bureau of Labor Statistics. (2011a). Quarterly Census of Employment and Wages: State and County Wages [Data File]. http://data.bls.gov/cgi-bin/surveymost?en+37

U.S. Bureau of Labor Statistics. (2011b). Consumer Price Index-All Urban Consumers: Southern Region All Items, 1982-1984 [Data File]. http://data.bls.gov/cgi-bin/surveymost?cu

U.S. Census Bureau. (2011a). Decennial Census, Summary Files 1 \& 3 [Data File]. $\mathrm{http} / / /$ factfinder.census.gov/servlet/DatasetMainPageServlet?program=ACS\&_submenuId=datasets_2\&_lang=en U.S. Census Bureau. (2011b). 2005-2009 American Community Survey 5-Year Estimates [Data File]. http://factfinder.census.gov/servlet/DatasetMainPageServlet?_program=ACS\&_submenuId=datasets_1\&_lang=e $\mathrm{n} \&$ ts $=$ 
Table 1. Population Trends, 2000 and 2010

\begin{tabular}{|c|c|c|c|}
\hline & $\mathbf{2 0 0 0}$ & $\mathbf{2 0 1 0}$ (Est.) & Percent Change \\
\hline 1-Mile Radius & 2,641 & 2,371 & $-10 \%$ \\
\hline 5-Mile Radius & 5,457 & 4,790 & $-12 \%$ \\
\hline 10-Mile Radius & 11,389 & 10,110 & $-11 \%$ \\
\hline 20-Mile Radius & 138,166 & 136,889 & $-1 \%$ \\
\hline
\end{tabular}

Table 2. Population by Age Cohort, 2000 and 2010

\begin{tabular}{|c|c|c|c|c|c|c|c|c|}
\hline \multirow{2}{*}{ Age Cohort } & \multicolumn{2}{|c|}{ 1-Mile Radius } & \multicolumn{2}{c|}{ 5-Mile Radius } & \multicolumn{2}{c|}{ 10-Mile Radius } & \multicolumn{2}{c|}{20 -Mile Radius } \\
\cline { 2 - 9 } & $\begin{array}{c}\text { Absolute } \\
\text { Change }\end{array}$ & $\begin{array}{c}\text { Annual } \\
\text { Average }\end{array}$ & $\begin{array}{c}\text { Absolute } \\
\text { Change }\end{array}$ & $\begin{array}{c}\text { Annual } \\
\text { Average }\end{array}$ & $\begin{array}{c}\text { Absolute } \\
\text { Change }\end{array}$ & $\begin{array}{c}\text { Annual } \\
\text { Average }\end{array}$ & $\begin{array}{c}\text { Absolute } \\
\text { Change }\end{array}$ & $\begin{array}{c}\text { Annual } \\
\text { Average }\end{array}$ \\
\hline Under 18 & -151 & $-2.3 \%$ & -325 & $-2.3 \%$ & -664 & $-2.4 \%$ & $-3,882$ & $-1.1 \%$ \\
\hline $18-24$ & -2 & $-0.1 \%$ & -23 & $-0.5 \%$ & -32 & $-0.3 \%$ & 1,000 & $0.8 \%$ \\
\hline $25-34$ & 24 & $0.9 \%$ & -40 & $-0.7 \%$ & -95 & $-0.7 \%$ & $-1,284$ & $-0.7 \%$ \\
\hline $35-44$ & -117 & $-3.8 \%$ & -241 & $-3.6 \%$ & -548 & $-3.8 \%$ & $-4,667$ & $-2.4 \%$ \\
\hline $45-54$ & -6 & $-0.2 \%$ & -19 & $-0.3 \%$ & -55 & $-0.4 \%$ & 1,201 & $0.6 \%$ \\
\hline $55-64$ & 37 & $1.4 \%$ & 71 & $1.4 \%$ & 210 & $1.8 \%$ & 4,824 & $3.4 \%$ \\
\hline 65 and Over & -54 & $-1.2 \%$ & -90 & $-1.1 \%$ & -93 & $-0.6 \%$ & 1,533 & $0.8 \%$ \\
\hline Total Population & $\mathbf{- 2 7 0}$ & $\mathbf{- 1 . 1 \%}$ & $-\mathbf{6 6 7}$ & $\mathbf{- 1 . 3 \%}$ & $\mathbf{- 1 , 2 7 9}$ & $\mathbf{- 1 . 2 \%}$ & $\mathbf{- 1 , 2 7 7}$ & $\mathbf{- 0 . 1 \%} \%$ \\
\hline
\end{tabular}

Table 3. Households by Race/Ethnicity, 2000 and 2010

\begin{tabular}{|c|c|c|c|c|c|c|c|c|}
\hline \multirow{2}{*}{ Age Cohort } & \multicolumn{2}{|c|}{ 1-Mile Radius } & \multicolumn{2}{|c|}{ 5-Mile Radius } & \multicolumn{2}{c|}{ 10-Mile Radius } & \multicolumn{2}{c|}{ 20-Mile Radius } \\
\cline { 2 - 9 } & $\mathbf{2 0 0 0}$ & $\mathbf{2 0 1 0}$ & $\mathbf{2 0 0 0}$ & $\mathbf{2 0 1 0}$ & $\mathbf{2 0 0 0}$ & $\mathbf{2 0 1 0}$ & $\mathbf{2 0 0 0}$ & $\mathbf{2 0 1 0}$ \\
\hline White/Caucasian & $28 \%$ & $23 \%$ & $24 \%$ & $21 \%$ & $29 \%$ & $28 \%$ & $47 \%$ & $44 \%$ \\
\hline African-America & $71 \%$ & $76 \%$ & $75 \%$ & $78 \%$ & $70 \%$ & $71 \%$ & $49 \%$ & $52 \%$ \\
\hline All Other Races & $1 \%$ & $1 \%$ & $1 \%$ & $1 \%$ & $2 \%$ & $3 \%$ & $5 \%$ & $6 \%$ \\
\hline
\end{tabular}

Figures may not sum to totals due to rounding.

Table 4. Teacher Turnover Rates, 2009-2010 Academic Year

\begin{tabular}{|c|c|c|c|}
\hline Grade Level & $\begin{array}{c}\text { Halifax County } \\
\text { Public Schools }\end{array}$ & $\begin{array}{c}\text { Weldon City } \\
\text { Schools }\end{array}$ & $\begin{array}{c}\text { Roanoke Rapids } \\
\text { Graded School District }\end{array}$ \\
\hline Elementary Schools & $34 \%$ & $25 \%$ & $7 \%$ \\
\hline Middle Schools & $37 \%$ & $19 \%$ & $20 \%$ \\
\hline High Schools & $34 \%$ & N/A & $13 \%$ \\
\hline
\end{tabular}

Table 5. Median Household Income by Race (2010 Dollars), 1999 and 2010

\begin{tabular}{|c|c|c|c|c|c|c|c|c|}
\hline \multirow{2}{*}{ Age Cohort } & \multicolumn{2}{|c|}{ 1-Mile Radius } & \multicolumn{2}{|c|}{ 5-Mile Radius } & \multicolumn{2}{c|}{ 10-Mile Radius } & \multicolumn{2}{c|}{20 -Mile Radius } \\
\cline { 2 - 9 } & $\mathbf{1 9 9 9}$ & $\mathbf{2 0 1 0}$ & $\mathbf{1 9 9 9}$ & $\mathbf{2 0 1 0}$ & $\mathbf{1 9 9 9}$ & $\mathbf{2 0 1 0}$ & $\mathbf{1 9 9 9}$ & $\mathbf{2 0 1 0}$ \\
\hline White/Caucasian & $\$ 48,345$ & $\$ 44,844$ & $\$ 49,244$ & 45,500 & $\$ 49,969$ & $\$ 46,194$ & $\$ 54,236$ & $\$ 49,204$ \\
\hline African-America & $\$ 23,034$ & $\$ 20,559$ & $\$ 26,070$ & 23,577 & $\$ 29,164$ & $\$ 26,514$ & $\$ 31,313$ & $\$ 28,548$ \\
\hline Difference & $\mathbf{\$ 2 5 , 3 1 2}$ & $\mathbf{\$ 2 4 , 2 8 4}$ & $\mathbf{\$ 2 3 , 1 7 4}$ & $\mathbf{\$ 2 1 , 9 2 3}$ & $\mathbf{\$ 2 0 , 8 0 5}$ & $\mathbf{\$ 1 9 , 6 8 1}$ & $\mathbf{\$ 2 2 , 9 2 3}$ & $\mathbf{\$ 2 0 , 6 5 5}$ \\
\hline Income Differential & $\mathbf{5 2 \%}$ & $\mathbf{5 4 \%}$ & $\mathbf{4 7 \%}$ & $\mathbf{4 8 \%}$ & $\mathbf{4 2 \%}$ & $\mathbf{4 3 \%}$ & $\mathbf{4 2 \%}$ & $\mathbf{4 2 \%}$ \\
\hline
\end{tabular}


Table 6. Median Household Income by Race (2010 Dollars), 1999 and 2010

\begin{tabular}{|c|c|c|c|c|c|c|}
\hline \multirow{2}{*}{ Income Source } & \multicolumn{2}{|c|}{ Town of Enfield } & \multicolumn{2}{c|}{ Halifax County } & \multicolumn{2}{c|}{ United States } \\
\cline { 2 - 7 } & $\mathbf{1 9 9 9}$ & $\mathbf{2 0 0 5 - 2 0 0 9}$ & $\mathbf{1 9 9 9}$ & $\mathbf{2 0 0 5 - 2 0 0 9}$ & $\mathbf{1 9 9 9}$ & $\mathbf{2 0 0 5 - 2 0 0 9}$ \\
\hline Wage or Salary & $63 \%$ & $61 \%$ & $68 \%$ & $65 \%$ & $78 \%$ & $77 \%$ \\
\hline Self-Employment & $4 \%$ & $5 \%$ & $7 \%$ & $8 \%$ & $12 \%$ & $12 \%$ \\
\hline Interest \& Dividends & $15 \%$ & $15 \%$ & $20 \%$ & $15 \%$ & $36 \%$ & $25 \%$ \\
\hline Social Security & $36 \%$ & $46 \%$ & $34 \%$ & $41 \%$ & $26 \%$ & $27 \%$ \\
\hline Supplemental Security & $18 \%$ & $19 \%$ & $11 \%$ & $10 \%$ & $4 \%$ & $4 \%$ \\
\hline Public Assistance & $14 \%$ & $5 \%$ & $7 \%$ & $2 \%$ & $3 \%$ & $2 \%$ \\
\hline Retirement Savings & $15 \%$ & $13 \%$ & $19 \%$ & $18 \%$ & $17 \%$ & $17 \%$ \\
\hline Other Sources & $22 \%$ & $18 \%$ & $17 \%$ & $17 \%$ & $13 \%$ & $14 \%$ \\
\hline With Earnings & $\mathbf{6 5} \%$ & $\mathbf{6 3} \%$ & $\mathbf{7 0} \%$ & $\mathbf{6 7 \%}$ & $\mathbf{8 1 \%}$ & $\mathbf{8 0} \%$ \\
\hline Without Earnings & $\mathbf{3 5} \%$ & $\mathbf{3 7 \%}$ & $\mathbf{3 0} \%$ & $\mathbf{3 3 \%}$ & $\mathbf{1 9 \%}$ & $\mathbf{2 0 \%}$ \\
\hline
\end{tabular}

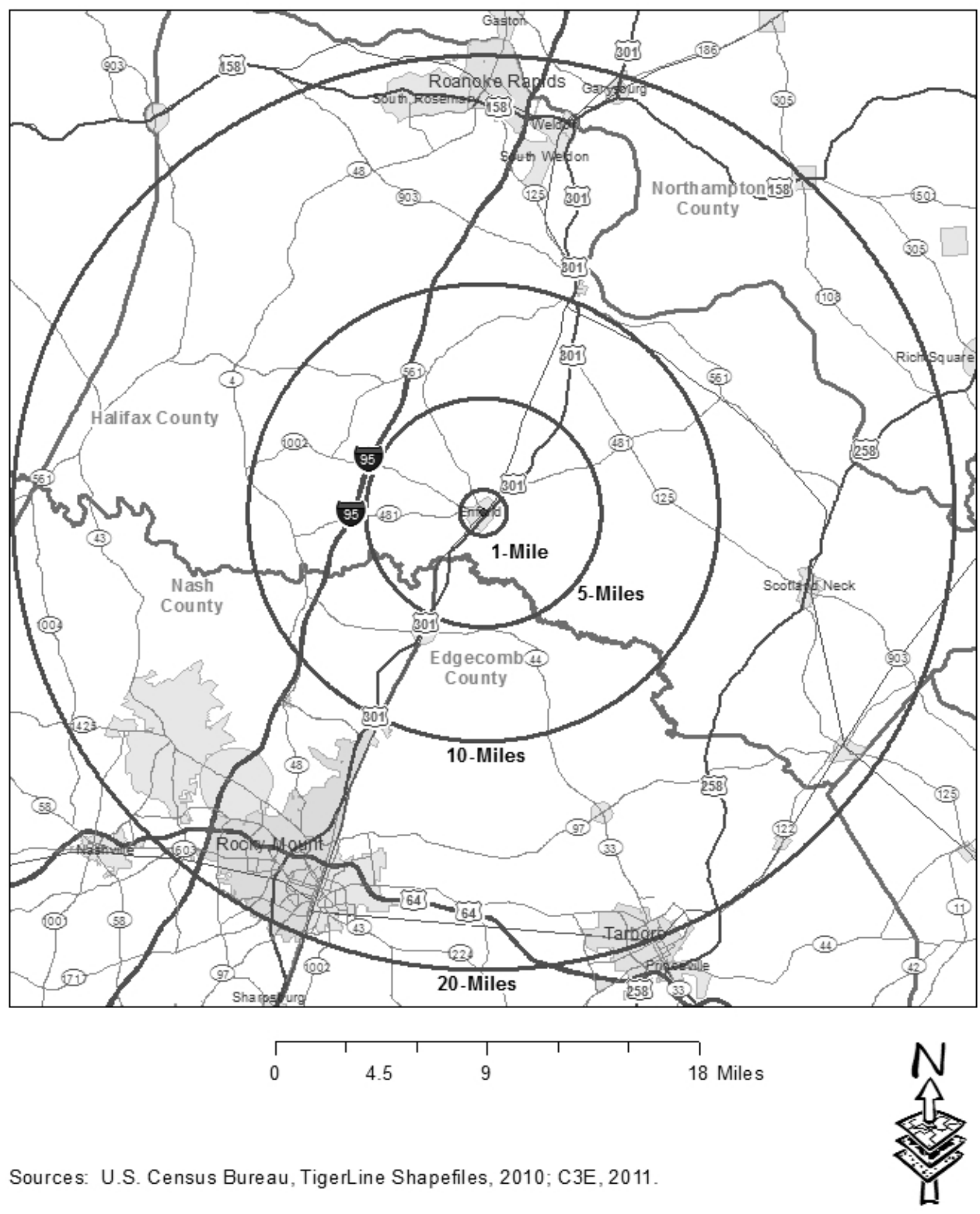

Figure 1. Study Area Geographic Boundaries 